\title{
SOYBEAN SEED [Glycine max. (L.) MERRILL] QUALITY IN RELATION TO POD POSITION AND STORAGE PERIOD El-Emam, A. A. M. ${ }^{1}$ and Hoda, M. G. Elshaboury ${ }^{2}$ Seed Tech. Res. Dep., ${ }^{1}$ Legume Crops Res. Dep., ${ }^{2}$ Field Crops Res. Institute, Agric. Res. Center, Giza
}

\begin{abstract}
ABISTRACT
Viability and performance of soybean Seeds were obviously affected by pod position on the plant and storage period so that they don't have germination capacity above the standard of certified seed $(75 \%)$ and produce pour performance under field conditions. The objective of the present research was to determine the effect of pod position on the plant and open-air storage conditions for 3,6 and 18 months on soybean seed quality as expressed by germination traits, seed and seedling vigor under optimal and sub-optimal conditions in the laboratory and the field during 2012 and 2013 seasons. The results revealed that seeds from the upper third part of the plant tended to have high quality including seed weight, laboratory germination before and after aging, germination rate, seedling length and its dry matter, electrical conductivity as well as field emergence. Seed quality was also influenced by storage period, the longer the period the lower seed quality. However, soybean seed can be stored safety without dramatic changes in quality attributes for 6 months. Seed deteriorating was related to the genetic makeup .Protein and oil seed content within each cultivar were not significantly affected by storage period. Oil acidity, acid value and free fatty acids were increased with increasing storage period, while Peroxide value was decreased... However, prolonging storage period up to 18 months (carriedover seeds) should be under controlled conditions in order to maintain seed quality unchanged. Furthermore, economical study is need to determining the benefit of using certain part of the plant for future plant purpose as compared with using the whole harvested seeds.
\end{abstract}

Keywords: Soybean , Glycine max ,Seed position,, Storage

\section{INTRODUCTION}

Seed quality is an important parameter for commercialization and processing of the seed lot and can affect the value of the product and its derivatives. According to Brooker et al. (1992),the main characteristics that determine soybean (Glycine max I. Merr.) quality are low and uniform moisture content at and after harvest during storage; relatively low temperature in storage, and chemical composition of the seed namely oil and protein contents. Seed position on the plant was found to be one the components that affect physical and physiological seed attributes, Ahmed (2010). Hampton et al. (1996) and Adam et al. (1989) found that seed in the lower third of the plant tended to have lower 1000 -seed weight; to be inferior germination and higher electrical conductivity after immersing in water indicating a lower vigor. However, seed quality was improved by harvesting the pods of the upper and medium third separately from those of the lower third. On the other hand, seeds from any part of the plant will have similar physiological quality, if harvested at the proper stage.

It is well known that moisture content of the seed is of primary importance for prolonged maintenance of viability during the storage period. This especially true for oil seeds such as soybean seed. Bardave and 
Moreno (1982) found that viability loss is primarily due to the effect of storage moisture and temperature rather than the effect of storage fungi. Burris (1980) found in soybean seed significant genotypic effects for germination and vigor and the genotypic effects on storability which was correlated with vigor suggests that selection for vigor may be used for improving storability. Deterioration of seed during storage is manifested as a reduction in percent germination while those seeds that do germinate, produce weak seedling, which ultimately affect the growth and yield of crop plant, Tekrony et.al. (1993). Furthermore, large variation in quality loss of soybean seed between cultivars during storage, Wein and Kueneman (1981). The viability of oil seeds such as soybean seed is difficult to maintain during storage because there is a slight tendency to be relatively short-lived, Periesly (1986). Accelerated aging of seeds over several days of exposure to high temperature and high humidity has been recognized as a good predictor of seed storability and quantitative changes in lipid peroxidation and subsequent peroxide accumulation has been taken place. Wilson and McDonald (1992) reported that Lipid peroxidation is a basic cause of deterioration and is one of the first changes in seed biochemistry detectable during storage. In addition, increments of free fatty acids and a decrease of antioxidation in soybean aged naturally ( Senaratna et al., (1980).

The objective of the present research was to determine the effect of pod position on the plant and open-air storage on soybean seed quality as expressed by germination traits and seedling vigor under optimal and suboptimal conditions in the laboratory and the field.

\section{MATERIALS AND METHODS}

Seed samples of three soybean cultivars namely Giza 22, Hybrid 30 and Giza 35 were collected from seed production program conducted at Gemmeiza Research Station, Agricultural Research Centre (about $130 \mathrm{Km}$ from Cairo) during 2011 harvesting season. These samples were represented from three different positions on the plant (upper, medium and bottom). The samples were divided into two parts. One part was utilized for laboratory and field experiments during 2012 and 2013 seasons, the second part was devoted for storage trial starting at the first of November 2011 under open- air condition of common storage.

Laboratory experiments were conducted at Seed Technology Research Department at Giza and Mansoura while Field experiments were carried out at Gemmeiza research station, Agricultural Research Centre (ARC), during 2012 and 2013 years. Seed samples were subjected to the following laboratory tests in completely randomized block design:

Standard germination test: Eight replications of 50 seeds of each cultivar were planted in plastic boxes of $40 \times 20 \times 20 \mathrm{~cm}$ dimensions and contained sterilized sand. The boxes were watered and kept at $25 \mathrm{c}^{\circ}$ in an incubated champer for 8 days. Normal seedling were counted at 4 and 8 days (first and final accounts) according to the international rules of ISTA (1999). Germination percentage was calculated using the formula outlined by ISTA rules (1999), where (germination \%) = Number of normal seedling number of 
seed tested $X$ 100. Seedling vigor was measured by germination rate and according to the equation outlined by Bartlett (1937) as follows:

$$
\begin{aligned}
\text { Germination Rate }= & \mathbf{a}+(\mathbf{a}+\mathbf{b})+(\mathbf{a}+\mathbf{b}+\mathbf{c})+\cdots \ldots+(\mathbf{a}+\mathbf{b}+\mathbf{c}+\mathbf{m}) \\
& \div \mathbf{n}(\mathbf{a}+\mathbf{b}+\mathbf{c}+\cdots .+\mathbf{m})
\end{aligned}
$$

Where $(a, b, c$ and $m)=$ number of seeds emerged at the first count, second and final account and $\mathrm{n}$ is the number of counts.

At the final count, ten normal seedlings from each replicate were randomly taken to measure seedlings length and then seedling dry matter by dried in hot_air oven at $85 \mathrm{c}^{\circ}$ for 12 hours according to Krishnasamy and Seshu (1990).

Accelerating Aging Test:

was carried out according to ISTA rules (1999), where one hundred seeds each in four replicates are tied in a fine muslin cloth, then placed in a jar on a wire mesh. The lower part of the jar is filled with water. There were no direct contact between water in the jar and the seed in the muslin cloth. The jar was covered with the lid and sealed with paraffin wax to make it air tight. The jar was placed in an accelerated aging chamber maintain at $40 \pm 2$ $\mathrm{C}^{\circ}$ for 48 hours. After this period the seed package was removed and cooled in a desecrator. Then the seeds were subjected to normal germination test.

\section{Electrical conductivity:}

was evaluated according to the procedures outlined by Matthews and Alison (1987). The HANNA conductivity meter (Hi 80333) was used, where fifty seeds in three replications of tested samples were weighted to 2 decimal numbers and placed in $500 \mathrm{ml}$ flask and $250 \mathrm{ml}$ of distilled water was added. The flask was cover and placed in an incubator at a constant temperature of $20 \mathrm{C}^{\circ}$ for 24 hours after which the contents of the flask; were gently stirred. The electrical conductivity was measured in the solution after removing the seeds. The results were reported as ( $\mu$ mhosig seeds).

\section{Field emergence:}

\section{$E C=$ Reading of replicate / weight of seeds}

Four replications of 100 seeds of each position on the plant (upper medium and low) of each cultivar were sown in a randomized block design at Gemmeiza Agricultural Research station .Sowing dates were 6 and 11 June during 2012 and 2013 seasons, respectively. All cultural practices concerning land preparation irrigation were done as recommended for growing soybean crop. Seedling emergence were recorded at time intervals until constant (10, 15 and 20 days from seed sowing) and the highest figures were used. Other calculation was made including relative field emergence or field emergence index (denote to the percentage of viable produced plants in the field / seed germination as determined in the laboratory.

\section{Storage Trial:}

seed samples were stored in cloth bags at room temperature (16-30 $\left.\mathrm{c}^{\circ}\right)$ and relative humidity ranged from $42-63 \%$ ). Four 100 seed samples of each cultivar were drown for germination test as mentioned before. Additional samples were utilized for chemical analysis according to the procedures outlined by (A.O.A.C., 1960) after 3, 6 and 18 months. Chemical analysis was 
included determining of seed moisture, oil and protein contents .Oil acidity, acid value, free fatty acids and peroxide value were also determined.

Collected data were subjected to standard analysis of variance according to the procedures out lined by steel and Torrie (1980).Simple coefficients were calculated to compare the association between values of seed germination under optimal and aging germination, seedling vigor, electrical conductivity under laboratory conditions and field emergence.

\section{RESULTS AND DISCUCTION}

Table (1) shows average of 100 seed weight, Standard Germination, Field Emergence, and Field emergence Index of seeds of different plant positions at different dates (combined data) during 2012 and 2013 seasons. The Hybrid 30 gave the high average of seed weight followed by Giza 22 and Giza 35, respectively, which may attributed mainly to the variation in the genetic makeup and cultural practices (i.e. harvesting time ,threshing method and storage period) .The results reported by El-Abady et al. (2012) showed that seed germination and seedling vigor of Cultivar Giza 21 were higher than those of Giza 35 and Giza 111. The germination percentage under optimal conditions was ranged between ( 81 to $89 \%$ ) that is above the standard of certified seeds $(75 \%)$. It was obvious that seed of the upper third part of the plant was relatively good quality than other parts. Significant differences in germination percentage of seed of various cultivars were achieved. Llliprontijr et al. (2000) reported that higher seed viability and increased length of normal seedling in soybean from upper to lower main stem sections,they also opined that seeds from earlier pods (b0ttom nodes were deteriorated before harvest due to aging. The results of field emergence and field emergence index show similar trend as those of standard germination. The correlation coefficient for the relationship between seed weight and Field emergence was significant $(R=0.695 \%)$. The correlation coefficient for the relationship between standard germination and Field emergence was highly significant ( $R=0.849 * *)$ indicating the importance of purchasing seed of high germination written on the tag of seed bag. However, the performance of seed under field conditions was so far from that under laboratory conditions so that it was reduced more than $25 \%$. These results revealed the importance of using good quality seed at planting in the field, and therefore, precaution should be taken when calculating seeding rate to achieve the indented plant population. The standard germination value of certified soybean should adjust to be above $(75 \%)$, I.E. (85\%). Furthermore, The results revealed the higher seed potential under field conditions required at least 15 days as compared with that under laboratory conditions ( 8 days) as recommended by international rules of seed testing (ISTA), which emphasize the importance of using vigorous seeds at planting. The results raise a question as to the economical benefit of using seeds of the upper third part of the plant for plant purpose and the remaining seeds for commercial one. Further research includes an economical study is need to answer the supposed question. The Results of field emergence index were almost followed by the trend of field emergence, 
the higher field emergence, the higher field index. The results are generally in agreement with those obtained by Elmanzlawy, Amal (2010).

Table (1): 100-seed weight, standar germination, field emergence and field emergence index of seeds of different cultivars and pod position of plant, combined data of 2012 and 2013 seasons.

\begin{tabular}{|c|c|c|c|c|c|c|c|c|}
\hline Cultivar & 100 seed & & Field & emergen & ce (\%) & Field e & $\begin{array}{c}\text { mergenc } \\
(\%)\end{array}$ & e index \\
\hline Pod Position & $\begin{array}{c}\text { (gm) } \\
\end{array}$ & (\%) & 10 days & 15 days & 20 days & 10 days & 15 days & 20 days \\
\hline \begin{tabular}{|c} 
Giza 22 \\
Top \\
Medium \\
Bottom
\end{tabular} & $\begin{array}{l}15.67 \\
14.95 \\
14.23\end{array}$ & $\begin{array}{l}89 \\
87 \\
82\end{array}$ & $\begin{array}{l}43 \\
40 \\
40\end{array}$ & $\begin{array}{l}63 \\
59 \\
55\end{array}$ & $\begin{array}{l}65 \\
61 \\
59\end{array}$ & $\begin{array}{l}48.3 \\
46.0 \\
48.8\end{array}$ & $\begin{array}{l}70.8 \\
67.8 \\
67.1\end{array}$ & $\begin{array}{l}73.0 \\
70.1 \\
72.0\end{array}$ \\
\hline Average (\%) & 14.95 & 86 & 41 & 59 & 62 & 47.7 & 68.8 & 71.7 \\
\hline \begin{tabular}{|c} 
Hybrid 30 \\
Top \\
Medium \\
Bottom
\end{tabular} & $\begin{array}{l}15.96 \\
15.80 \\
15.33\end{array}$ & $\begin{array}{l}92 \\
88 \\
84\end{array}$ & $\begin{array}{l}44 \\
43 \\
43\end{array}$ & $\begin{array}{l}62 \\
60 \\
58\end{array}$ & $\begin{array}{l}63 \\
61 \\
60\end{array}$ & $\begin{array}{l}47.8 \\
48.9 \\
51.2\end{array}$ & $\begin{array}{l}67.4 \\
68.2 \\
69.0\end{array}$ & $\begin{array}{l}68.5 \\
69.3 \\
71.4\end{array}$ \\
\hline Average (\%) & 15.60 & 88 & 43 & 60 & 71 & 49.3 & 68.2 & 79.7 \\
\hline $\begin{array}{c}\text { Giza } 35 \\
\text { Top } \\
\text { Medium } \\
\text { Bottom }\end{array}$ & $\begin{array}{l}13.66 \\
13.60 \\
13.34\end{array}$ & $\begin{array}{l}84 \\
81 \\
81\end{array}$ & $\begin{array}{l}39 \\
36 \\
34\end{array}$ & $\begin{array}{l}61 \\
58 \\
58\end{array}$ & $\begin{array}{l}61 \\
59 \\
59\end{array}$ & $\begin{array}{l}46.4 \\
44.4 \\
42.0\end{array}$ & $\begin{array}{l}72.6 \\
71.6 \\
7.1 .6\end{array}$ & $\begin{array}{l}72.6 \\
72.8 \\
72.8\end{array}$ \\
\hline $\begin{array}{l}\text { Average (\%) } \\
\text { L.S.D.at 5\% }\end{array}$ & $\begin{array}{c}13.53 \\
1.12 \\
\end{array}$ & $\begin{array}{c}82 \\
2 \\
\end{array}$ & $\begin{array}{c}38 \\
3\end{array}$ & $\begin{array}{c}59 \\
2 \\
\end{array}$ & $\begin{array}{c}60 \\
2 \\
\end{array}$ & $\begin{array}{c}44.3 \\
2.2 \\
\end{array}$ & $\begin{array}{c}71.9 \\
1.3 \\
\end{array}$ & $\begin{array}{c}72.7 \\
1.1 \\
\end{array}$ \\
\hline
\end{tabular}

Table (2) show the aging germination percentage of the hybrid 30 seeds was higher (78\%) than those of the cultivars Giza 22 and Giza 35 $(66 \%, 60 \%$, respectively).This may reflect the effect of the variation of genetic constitution of included genotypes. The aging test has become as a good test for vigor particularly for soybean and to indicate the optional storability (Tekrony, 1993), he reported that many seed weaknesses are not detected by standard germination and therefore the demand for vigor test such as aging test is greatly increased. The correlation coefficient for the relationship between aging germination (Table 2) and standard germination (Table 1) was highly significant $\left(R=0.801^{*}\right)$, but it was insignificant with Field emergence $(R=0.535)$, The electrical conductivity of seed steep water showed good quality seed of the hybrid 30 compared with that of Giza 22 and Giza 35, where the lower conductivity value the better quality seed. The correlation coefficient for the relationship between conductivity values (Table 2) and standard germination (Table 1) was significant $\left(R=-787^{*}\right)$, but it was insignificant with Field emergence $(R=-0.458)$. Within each cultivar, the results of conductivity test indicated that vigorous seeds were obtained from the upper third part of the plant followed by medium and bottom parts, respectively vigorous seed is of great importance to achieved a good field emergence as it has shown in Table (1). Moreover, vigorous seeds are expected to express their self and produce vigorous plants in the field and are cobble of producing high yield. Actually, a combination of several vigor tests 
provides the most information about quality seed that will perform well under a wide range of conditions. The studies made by Eraky et. al., (2010) and ElGarhy et. al., (2013) came to the same conclusion.

Table (2): Aging germination, germination rate, seedling length and its dry matter and electrical conductivity of seeds of different cultivars and pod position of plant, combined data of 2012 and 2013 seasons.

\begin{tabular}{|c|c|c|c|c|c|}
\hline Pod position & $\begin{array}{c}\text { Aging } \\
\text { germination } \\
\text { (\%) }\end{array}$ & $\begin{array}{c}\text { Germination } \\
\text { rate }\end{array}$ & $\begin{array}{c}\text { Seedling } \\
\text { length (cm) }\end{array}$ & $\begin{array}{c}\text { Seedling dry } \\
\text { matter (gm) }\end{array}$ & $\begin{array}{c}\text { Electrical } \\
\text { conductivity } \\
\text { (umhosigseed) }\end{array}$ \\
\hline $\begin{array}{c}\text { Giza 22 } \\
\text { Top } \\
\text { Medium }\end{array}$ & 70 & 0.667 & 22.8 & 0.632 & 4.52 \\
Bottom & 66 & 0.631 & 22.5 & 0.620 & 4.62 \\
\hline Average (\%) & 61 & 0.606 & 21.1 & 0.604 & 4.84 \\
\hline Hybrid 30 & 66 & 0.635 & 22.1 & 0.618 & 4.66 \\
Top & & & & & \\
Medium & 80 & 0.692 & 24.3 & 0.764 & 3.44 \\
Bottom & 76 & 0.668 & 23.4 & 0.733 & 3.78 \\
\hline Average (\%) & 78 & 0.655 & 22.7 & 0.719 & 3.99 \\
\hline Giza 35 & & 0.671 & 23.5 & 0.739 & 3.74 \\
Top & & & & & \\
Medium & 63 & 0.598 & 20.8 & 0.572 & 5.02 \\
Bottom & 58 & 0.586 & 20.1 & 0.566 & 5.05 \\
\hline Average (\%) & 60 & 0.568 & 19.4 & 0.554 & 5.08 \\
\hline L.S.D. at 5\% & 1.4 & 0.584 & 20.1 & 0.564 & 5.05 \\
\hline
\end{tabular}

Table (3) show that seed weight was slightly influenced by storage period until 18 months regardless of the variety seed. However, there were significant differences in seed weight of different cultivars, where cultivar Hybrid 30 has high seed weight followed by Giza 22 and Giza 35 cultivars, respectively. Seed germination values showed the same trend as seed weight values until 6 months and such values were reduced significantly after 18 months so that germination percentage was lower that of certified seed $(75 \%)$, suggested using controlled conditions (low temperature of about $10 \mathrm{C}^{\circ}$ and low relative humidity of about $60 \%$ as recommended by Byrd and Delouche (1971) for carried over seeds (18 months in storage). The values of electrical conductivity (EC) was increased as storage period was increased. Colete et. al., (2004) and Viera et. al., (2008) reported that the conductivity test measures the electrolytes that leach out the seeds when they immersed in water and this leakage is an indication of seed vigor. The value of EC increased as the period and temperature of the storage increased. Cultivar Seeds were varied in moisture content where cultivar Hybrid 30 has lower moisture followed by Giza 22 and Giza 35 cultivars, respectively. Furthermore, seed moisture contents generally increased as storage period increased. Such increase was significant after 18 months under open-air storage conditions as compared with other periods (Table 3). Seed 
protein and its oil content was slightly decreased as storage period was increased.

Table (3): Effect of storage period and cultivars on 100-seed weight, germination percentage, electrical conductivity and seed composition (moisture, protein and oil).

\begin{tabular}{|c|c|c|c|c|c|c|}
\hline $\begin{array}{l}\text { Characters } \\
\text { Storage } \\
\text { Period }\end{array}$ & $\begin{array}{c}\text { 100-seed } \\
\text { Weight } \\
\text { (gm) }\end{array}$ & $\begin{array}{c}\text { Seed } \\
\text { germination } \\
(\%)\end{array}$ & $\begin{array}{c}\text { EC (umohs } \backslash \mathrm{g} \\
\text { seed) }\end{array}$ & $\begin{array}{c}\text { Moisture } \\
(\%)\end{array}$ & $\begin{array}{l}\text { Protein } \\
(\%)\end{array}$ & $\begin{array}{l}\text { Oil } \\
(\%)\end{array}$ \\
\hline $\begin{array}{l}0 \text { month } \\
\text { Giza } 22 \\
\text { Hybrid } 30 \\
\text { Giza 35 }\end{array}$ & $\begin{array}{l}15.67 \\
16.55 \\
15.53\end{array}$ & $\begin{array}{l}86 \\
88 \\
82\end{array}$ & $\begin{array}{l}4.66 \\
3.74 \\
5.05\end{array}$ & $\begin{array}{l}12.54 \\
12.21 \\
12.86\end{array}$ & $\begin{array}{l}37.24 \\
37.49 \\
35.11\end{array}$ & $\begin{array}{l}25.82 \\
25.39 \\
25.95\end{array}$ \\
\hline \begin{tabular}{|l}
3 month \\
Giza 22 \\
Hybrid 30 \\
Giza 35
\end{tabular} & $\begin{array}{l}15.72 \\
16.56 \\
15.53\end{array}$ & $\begin{array}{l}86 \\
86 \\
81\end{array}$ & $\begin{array}{l}4.67 \\
4.73 \\
5.09\end{array}$ & $\begin{array}{l}12.60 \\
12.30 \\
12.90\end{array}$ & $\begin{array}{l}37.25 \\
37.58 \\
37.25\end{array}$ & $\begin{array}{l}25.78 \\
25.33 \\
25.91\end{array}$ \\
\hline $\begin{array}{l}6 \text { month } \\
\text { Giza } 22 \\
\text { Hybrid } 30 \\
\text { Giza } 35\end{array}$ & $\begin{array}{l}15.77 \\
16.62 \\
15.60\end{array}$ & $\begin{array}{l}82 \\
83 \\
78\end{array}$ & $\begin{array}{l}4.75 \\
4.78 \\
5.15\end{array}$ & $\begin{array}{l}12.80 \\
12.50 \\
13.06\end{array}$ & $\begin{array}{l}37.29 \\
37.57 \\
37.34\end{array}$ & $\begin{array}{l}25.72 \\
25.21 \\
25.80\end{array}$ \\
\hline $\begin{array}{l}18 \text { month } \\
\text { Giza } 22 \\
\text { Hybrid } 30 \\
\text { Giza } 35\end{array}$ & $\begin{array}{l}15.83 \\
16.64 \\
15.43\end{array}$ & $\begin{array}{l}63 \\
65 \\
63\end{array}$ & $\begin{array}{l}5.06 \\
4.87 \\
5.32\end{array}$ & $\begin{array}{l}13.44 \\
13.65 \\
13.95\end{array}$ & $\begin{array}{l}37.35 \\
37.65 \\
37.39\end{array}$ & $\begin{array}{l}25.11 \\
25.02 \\
25.61\end{array}$ \\
\hline L.S.D. at $5 \%$ & 0.12 & 2.2 & 0.28 & 0.22 & 0.21 & 0.16 \\
\hline
\end{tabular}

The correlation coefficient for the relationship between seed germination and electrical conductivity at times intervals of storage was significant $\left(R=0,590^{*}\right.$ ). Protein and oil seed content within each cultivar were not significantly affected by storage period. Cultivar seeds were varied in protein and oil content where cultivar Hybrid 30 has high seed protein followed by Giza 22 and Giza 35 cultivars. The correlation coefficient for the relationship between seed protein and oil contents values (Table 3 ) the correlation coefficient for the relationship between standard germination at times intervals of storage and protein and oil contents was insignificant $(R=0.148$ and 0.440 ,respectively).

Table (4) showed that oil acidity, acid value and free fatty acid were increased with increasing storage period, while Peroxide value was decreased. These results are in agreement with those outlined by Wilson and McDonald (1992) and El-Borai et. al., (1993). They reported that seed lipids are subjected continuous slow oxidation during storage resulting in the formation of hydroperoxides, oxygenated fatty acids and more radicals. The reduction might be attributed to the decomposition and hydrolysis of the formed hydroperoxides which was a result of increasing seed moisture content during storage, Oil acidity after 6 months storage did not differ significantly between soybean cultivars. This means that the cultivars reactthe same regardless of the storage period. However, oil acidity values after 18 months were significantly higher than those after 3 and 6 months storage. The correlation coefficient for the 
relationship between oil acidity, acid value free fat acids and peroxide value form the one hand and seed germination at times intervals of storage (Table 3) was highly significant $\left(R=0.967^{* *}, 0.968^{* *} 0.958^{* *}\right.$ and $\left.0.731^{*}\right)$ suggesting that biochemical changes that taken place in storage might be responsible for the reduction in seed viability and seedling vigor. The increase in free fatty acids is a symptom of seed deterioration caused by activation of lipase enzymes in fatty seed (Copeland, 1976). The statement made by Priestley (1986) explained that the reduction in seed germination and seedling vigor was mainly due to the products resulted from lipid peroxidation affecting denature DNA, hinder translation and transcription of protein and oxidize certain amino acids.

Table(4): Effect of storage period and cultivars on soybean seed chemical composition (oil seed, acid value, free fatty acid and peroxide nalues).

\begin{tabular}{|c|c|c|c|c|}
\hline Characters & $\begin{array}{c}\text { Acidity } \\
(\%)\end{array}$ & Acid value & Free fattyacid (\%) & $\begin{array}{l}\text { Peroxide } \\
\text { Vulue } \\
\text { meg } \backslash \mathrm{Kg}\end{array}$ \\
\hline \begin{tabular}{|l}
0 month \\
Giza 22 \\
Hybrid 30 \\
Giza 35
\end{tabular} & $\begin{array}{l}1.59 c \\
1.48 c \\
1.57 c\end{array}$ & $\begin{array}{l}0.76 \mathrm{~b} \\
0.73 \mathrm{~b} \\
0.78 \mathrm{~b}\end{array}$ & $\begin{array}{c}0.69 c \\
0.72 b c \\
0.82 b\end{array}$ & $\begin{array}{l}0.65 b \\
0.62 b \\
0.71 b\end{array}$ \\
\hline \begin{tabular}{|l}
3 month \\
Giza 22 \\
Hybrid 30 \\
Giza 35
\end{tabular} & $\begin{array}{c}1.65 b c \\
1.55 c \\
1.66 b c\end{array}$ & $\begin{array}{l}0.81 b \\
0.75 b \\
0.82 b\end{array}$ & $\begin{array}{l}0.81 b \\
0.73 b c \\
0.82 b\end{array}$ & $\begin{array}{l}0.64 b \\
0.62 b \\
0.69 b\end{array}$ \\
\hline \begin{tabular}{|l}
6 month \\
Giza 22 \\
Hybrid 30 \\
Giza 35
\end{tabular} & $\begin{array}{c}1.76 b \\
1.67 b c \\
1.84 b\end{array}$ & $\begin{array}{l}0.81 b \\
0.76 b \\
0.83 b\end{array}$ & $\begin{array}{c}0.85 a b \\
0.79 b \\
0.87 a b\end{array}$ & $\begin{array}{l}0.63 b \\
0.61 b \\
0.66 b\end{array}$ \\
\hline $\begin{array}{r}18 \text { month } \\
\text { Giza } 22 \\
\text { Hybrid } 30 \\
\text { Giza } 35\end{array}$ & $\begin{array}{l}2.43 a \\
2.32 a \\
2.49 a\end{array}$ & $\begin{array}{l}1.04 \mathrm{a} \\
2.32 \mathrm{a} \\
2.49 \mathrm{a}\end{array}$ & $\begin{array}{l}0.96 \mathrm{a} \\
0.94 \mathrm{a} \\
1.05 \mathrm{a}\end{array}$ & $\begin{array}{l}0.51 a \\
0.46 a \\
0.51 a\end{array}$ \\
\hline
\end{tabular}

Value in each column having the same letter are not significant different at $5 \%$ level

It was obvious that seed viability and performance are affected by internal factors namely seed pod position on the plant and external factors such as storage period. However, economical study is need to determining the economical benefit of using certain part of the plant for future plant purpose and prolonging storage period for 18 months (carried over seeds) under open air conditions provided that seed quality are remained unchanged.

\section{REFERENCES}

Adam, N. M.; M. B. Jr. McDonald and P. R. Henderlong (1989). The influence of seed position, planting and harvesting dates on soybean qaulity. Seed science and Technology, 17: 143-152. 
Ahmed, F.; M. S. A. Khan; M. A. Hossain; M. A. Jahan and A. J. Mridha (2010). Seed quality of soybean as affected by pod position and their subsequent effect on yield. J. Expt. Biosci. 1 (1): 1-6.

Bardave, D. M. and M. E. Moreno (1982). Efecto de diferents condiciones de almacenamient sobre la viabilidad de semilla de soya. Annales Instituto de Biologia. UNAM. Serie Bota`nnca, 47-53, 61-72.

Bartlett, M. S. (1937). Some samples of statistical method of research in research in agriculture and applied biology J. Roy. soc. 4:2.

Brooker, D. B.; F. W. Bakker-Arkema and C. W. Hall (1992). Drying and storage of grains and oil seed, springer, ISBN 0442205155, New York, United States.

Byrd, H. W. and J. C. Delouche (1971). Deterioration of soybean seed in storage. Proc. Assoc. of Seed Anal. 61: 41-57.

Colete, J. C. F; R. D. Vieira and A. S. Dutra (2004). Electrical conductivity and soybean seedling emergence. Scientia-Agricolar 61 (4): 386391.

Copeland, L. O. (1976). Principles of seed science and technology. Burgess publishing company. Minneapolis, Minnesota. p.115.

El-Abady, M. E.; A. A. M. EL-EMAM; S. E. Seadh and F. E. Usef (2012). Soybean seed quality as affected by cultivars,threashing methods and storage period. Research J. of seed scie. 5 (4): 115-125.

EL-Borai, N. A.; Nadia. A. El-Aidy and M. I. Elemery (1993). Effect of different storage periods on seed quality of three soybean cultivars. J. of Agricultural Sci.18: 2206-2211.

El-Garhy, A. M.; Amal, M. Elmanzlawy and Samya Z. Sayed (2013). Morphological, Biochemical evaluation of six soybean genotypes. Egypt J. plant Breed.17 (6): 127-141.

Elmanzlawy, Amal M. (2010). The credibility of some laboratory tests for predicting the performance of Soybean (Glycin max L. Merril) seed under field conditions. J. of plant Prod. Mansoura Univ.,1(11): 15151523.

Eraky, A. M. Hania; A. A. G. Ali; H. A. Rabie and M. I. Elemery (2010). The relationship between seed quality measurements and field emergence of soybean. Zagazig J. Agric. Res., 37 (4): 829-855.

Hampton, J.G.; L. Kahre; A.J.G. Van Gastel; K.G. Boyce; N. Leist; Wu. WenShi; W. Loubser; and W.J. Van Der Burg (1996). Quality seed - from production to evaluation. Seed Science and Technology, 22: 393407.

I. S. T. A. (1999). International Rules for Seed Testing, Seed Science and Technology. Proc. Int. Seed Test. Ass., 31 (1): 1-152.

Krishnasamy, V. and D.V. seshu (1990). Phsophine fumigation influence on rice seed germination and vigor. Crop Sci. 30: 28-85.

Illiprontijr, R.A.; W.J.M. Loommen; C.J. Langerak and P.C. Struik (2000). Time of pod set and position on the plant contribute to variation in quality of seeds within soybean seed lots. Netherlands J. Agril Sci. 48: 165-180.

Loubser, W. and W. J. Van Der Burg (1996). Quality seed from production to evaluation. Seed Science and Technology, 22: 393-407. 
Matthews, S. and A. P. Alison. (1987). Electrical Conductivity Test. Handbook of vigor Test Methods, $2^{\text {nd }}$ ed., 37-43. Published by ISTA.

Priestley D.A. (1986). Seed aging. Cornell Univ. Press. Ithaca, Ny.

Senaratna, T.; J. Gusse and D. Mckersie (1980). Age induced changes in cellular membranes of imbibed soybean seed axes. Physiologia Plantarum, 73, 85-91.

Steel, R. G. D. and J. H. Torrie (1980). Principles and procedures of statistics. $2^{\text {nd }}$ Ed. Mcgraw Hill Boo, Co., N.y., USA.

Tekrony, D. M.; O. Nelson; D. B. Egli and G. M. White (1993). Predicting soybean seed germination during warehouse storage. Seed Sci. \& Technol., 21: 127-137.

Vieira, R. D.; D. M. Tekrony; D. B. Egli; W. P. Bruenning and M. Panobianco (2008). Temerature during soybean seed storage and the amount of electrolytes of soaked seed solution. Scientia Agricols, 65 (5): 496-501.

Wein, H. C. and E. A. Kueneman (1981). Soybean seed deterioration in the tropics, Varietal differences and techniques for screening. Field Crops Res., 4: 123-132.

Wilson, D. O. and M. B. McDonald (1992). Mechanical damage in bean (Phaseolus Vulgaris I.) seed in mechanized and non-mechanized threshing system. Seed Sci. \& Technol., 20: 571-582.

\footnotetext{
جودة تقاوى فول الصويا وعلاقتها بوضع القرن على النبات ومدة التخزين

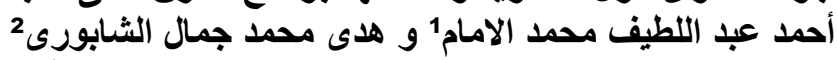
1 قسم بحوث تكنولوجيا البذور، 2 قسم بحوث المدام المحاصيل البقولية معهد بحوث المحاصيل الحقلية، مركز البحوث الزراعية-جيزة

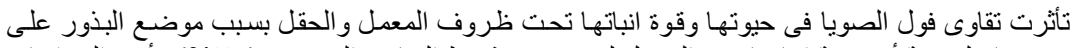

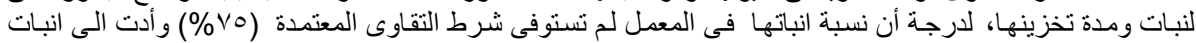

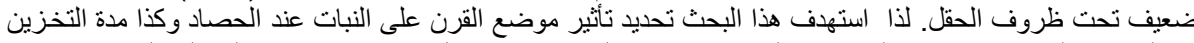

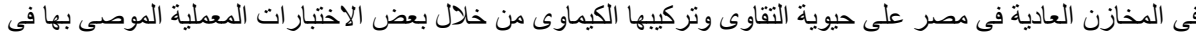

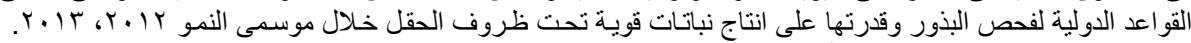

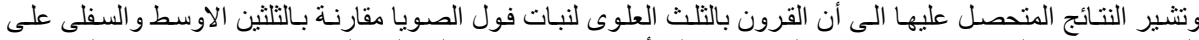

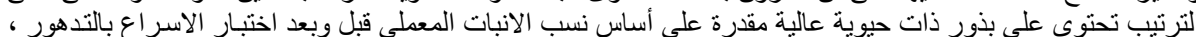

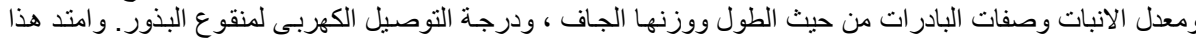

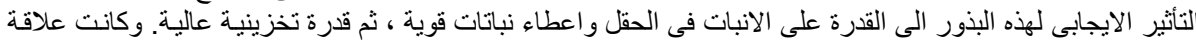

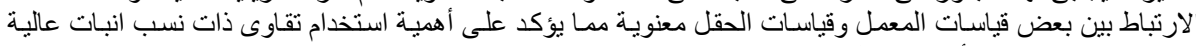

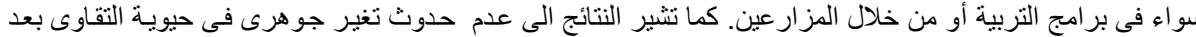

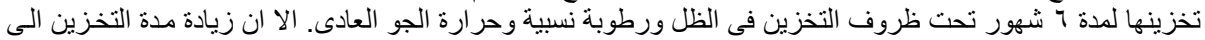

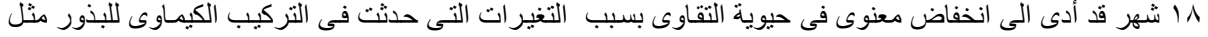

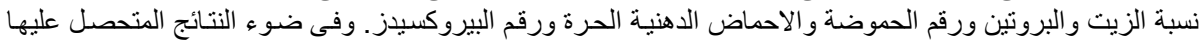

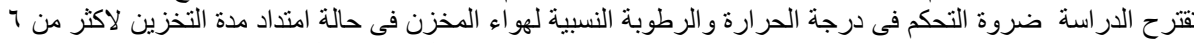

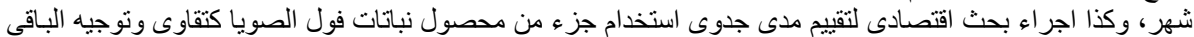

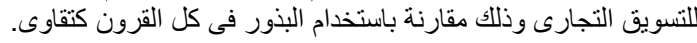

